Laurensia Nindyta Angelina Haspo, Aldri Frinaldil Penerapan Aplikasi SP4N-Lapor dalam Manajemen Pengaduan Masyarakat di Kota Solok

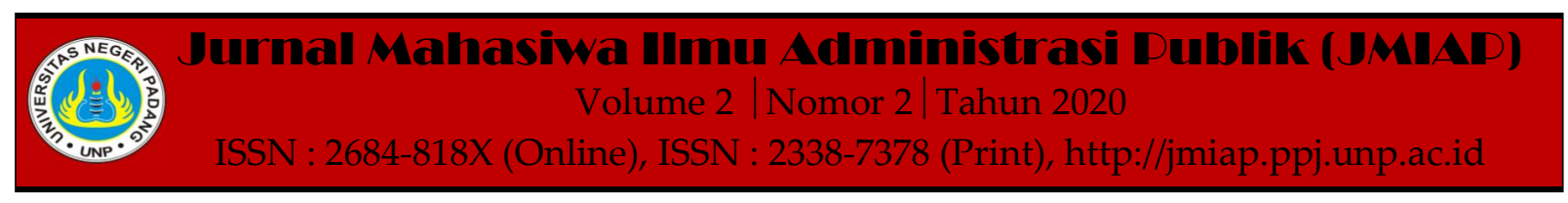

\title{
PENERAPAN APLIKASI SP4N-LAPOR DALAM MANAJEMEN PENGADUAN MASYARAKAT DI KOTA SOLOK
}

\author{
Laurensia Nindyta Angelina Haspo ${ }^{1(a)}$, Aldri Frinaldi ${ }^{2(b)}$ \\ ${ }^{1}$ Jurusan Ilmu Administrasi Negara, Universitas Negeri Padang \\ ${ }^{2}$ Jurusan Ilmu Administrasi Negara, Universitas Negeri Padang \\ a)laurensianindytaah@gmail.com, ${ }^{b}$ alfrinaldi@gmail.com
}

\begin{abstract}
This aims this study is to determine the Application of SP4N-LAPOR! In Solok city. SP4N-LAPOR! is an online application that is useful to make it easier for the public to submit complaints and for the government to find out the problems of public services in Solok city so that it is faster to be fixed. This research is a qualitative research which using descriptive methods. Informants were selected using a purposive sampling technique. In collecting data the research instruments were: form of interviews, observation and documentation studies. Data validity testing techniques was using the triangulation method. While the data analysis technique is done by reducing data, displaying data, and drawing conclusions and studies that have been determined. The results of the study showed the Implementation of SPAN-LAPOR aplication in public complain management in Solok city was not running well yet.
\end{abstract}

Keywords : Implementation, Complain Management, LAPOR Aplication

Corresponding author. Email.laurensianindytaah@gmail.com,alfrinaldi@gmail.com

How to cite this article. Haspo, L. Nindyta Angelina \& Frinaldi, A. (2020). Penerapan Aplikasi SP4NLapor dalam Manajemen Pengaduan Masyarakat di Kota Solok. Jurnal Mahasiwa Ilmu Administrasi Publik (JMIAP) Jurusan Ilmu Administrasi Negara Fakultas Ilmu Sosial Universitas Negeri Padang, Volume 2 (2), Hal. 26-33.

http://jmiap.ppj.unp.ac.id

ISSN : 2684-818X (Online), ISSN : 2338-7378 (Print)

Copyright $\bigcirc 2020$. Published by Pusat Kajian-Pemberdayaan dan Pelayanan Masyarakat (PK-P2M) FIS UNP Padang 


\section{PENDAHULUAN}

Salah satu pelayanan publik yang menggunakan media elektronik yaitu Layanan Aspirasi dan Pengaduan Online Rakyat (LAPOR!) sebagai tempat pengaduan masyarakat yang ada di Kota Solok. Sistem ini mengelola seluruh keluhan masyarakat untuk selanjutnya disampaikan kepada pihak-pihak terkait untuk meningkatkan pelayanan kepada masyarakat. Dalam Intruksi Presiden No. 3 Tahun 2003 tentang Kebijakan dan Strategi Nasional Pengembangan e-government, menjelaskan bahwa e-government merupakan upaya untuk mengembangkan penyelenggaraan kepemerintahan yang berbasis (menggunakan) elektronik dalam rangka meningkatkan kualitas layanan publik secara efektif dan efesien. (Instruksi Presiden, 2003). Oleh karena itu melalui pengembangan e-government ini dilakukan penataan sistem manajemen dan proses kerja di lingkungan pemerintah dengan mengoptimasikan pemanfaatan teknlogi informasi.

Dalam aplikasi SP4N-LAPOR! harus sesuai dengan mekanisme dan juga tata cara pengaduan seperti bagaimana dalam pengelolaannya tersebut. Sedangkan pengertian pengaduan yaitu adanya keluhan dari masyarakat yang dilakukan kepada pengelola agar pelaksana pelayanan yang tidak sesuai standar dapat diperbaiki dengan cepat serta terhadap pelaksana yang hanya mengabaikan kewajibannya terhadap pelayanan dan juga adanya pelanggaran dalam melaksanakan pengelolaan pengaduan tersebut. (Peraturan Presiden, 2013).

Dalam Undang-Undang tersebut diwajibkan atas pelaksana pelayanan publik agar dapat mempersiapkan sarana pengaduan dan memberikan tugas kepada yang kompeten dalam pengelolaan pengaduan. Adanya Perpres ini mengisyaratkan dibentuknya Sistem Pengelolaan Pengaduan Pelayanan Publik Nasional (SP4N). Untuk tindak lanjut Perpres tersebut juga telah diterbitkan Peraturan Mentri Pemberdayaan Aparatur
Negara dan Reformasi Birokrasi Nomor 24 Tahun 2014 tentang Pedoman Penyelenggaraan Pengelolaan Pengaduan Pelayanan Publik secara Nasional.

Diskominfo Kota Solok melakukan pengelolaan dalam pengaduan terhadap masyarakat melalui aplikasi LAPOR! Pemerintah Kota Solok ini yang dapat disampaikan melalui SMS ke 1708, dan bisa juga melalui websitenya yaitu https://www.lapor.go.id/instansi/pemerinta h-kota-solok, Twitter @LAPOR1708, Facebook yaitu@LAPOR PEMKO SOLOK, maupun dengan men-download aplikasinya yaitu SP4N LAPOR!. di Diskominfo Kota Solok mengatakan LAPOR! ini mulai disosialisasikan pada tahun 2017. Dalam pelaksanaannya, jika masyarakat ingin melapor dengan menggunakan LAPOR! PEMKO SOLOK maka cukup mudah untuk melakukannya. Masyarakat Kota Solok bisa mengaksesnya dengan membuka website maupun bisa dengan men-download aplikasi, jika sebelumnya masyarakat belum pernah mendaftar, maka terlebih dahulu melakukan pendaftaran ketika ingin memberikan laporan mengenai pelayanan publik (Sumber: Survei Diskominfo Kota Solok Tentang Pelayanan Publik, 2020).

Permasalahan umum yang terjadi berkaitan dengan keterbatasan dana yang dimiliki oleh pihak kantor sehingga kurangnya pra sarana seperti komputer dan laptop serta jaringan internet yang kurang baik yang menyebabkan loadingnya lama, kemudian kurangnya sosialisasi yang diberikan terhadap masyarakat, serta masyarakat kurang tertarik dan kurang paham terhadap guna dari aplikasi LAPOR! ini walaupun sudah disosialisasikan. Serta dalam melakukan proses penyelesaian laporan masyarakat dan lingkungan kerja yang kurang kondusif karena ruangan yang terlalu sempit mengakibatkan kurangnya cahaya yang masuk ke dalam ruangan serta kondisi ruangan yang kecil untuk menerima pelapor yang datang ke kantor menjadi tidak kondusif sehingga pegawai tidak nyaman untuk melakukan pekerjaan, maka 
hal tersebut tentunya akan mempengaruhi kualitas kerja yang dihasilkan.

Berdasarkan pengamatan penulis dapat diketahui bahwa penerapan aplikasi SP4NLAPOR! Pada Diskominfo Kota Solok masih belum maksimal sehingga masih terdapat beberapa hal yang akan ditingkatkan dan di perbaiki. Sehubungan dengan itu, maka penulis tertarik untuk dapat melakukan penelitian terkait permasalahan dengan judul "Penerapan Aplikasi SP4N-LAPOR Dalam Manajemen Pengaduan Masyarakat Di Kota Solok”

\section{TINJAUAN PUSTAKA}

\section{Penerapan E-Government}

Dalam penerapan E-Government ini yang harus diperhatikan yaitu bagaimana dalam suatu sistem pemerintahan tersebut berjalan dengan baik, karena dalam penerapan E-Government ini haruslah diperatikan sistem informasi yang baik, teratur serta sinegri dari masing-masing lembaga dalam pemerintahan tersebut, barulah diperoleh sub sistem informasi yang terjalin dengan baik. Dengan sistem informasi seperti yang diatas memudahkan pemerintah dalam menjalankan tugas dan fungsinya kepada masyarakat. Namun dalam mewujudkan sistem informasi seperti itu masing-masing bagi lembaga pemerintah harus memenuhi suatu standar sistem informasi, dalam standarnya seperti persyaratan minim untuk faktor-faktor dari sistem informasi ini.

Tujuan dalam penerapan E-Government ini didasarkan atas pemahaman negara asing yang sudah melakukan konsep EGovernment ini. Upaya yang dilakukannya dengan mencapai efisiensi,efeltivitas dan nilai ekonomi dari praktek layanan pemerintahan tersebut kepada masyarakat yang sebenarnya dalam tujuan ini lebih diharapkan lagi penerapan E-Government agar dapat mencapai hasil dengan adanya penerapan E-Government secara maksimal.

Dalam pengimplementasian aplikasi EGovernment ini mengigat seberapa banyaknya tugas serta tanggung jawab pemerintah, karena berfungsi dalam mengatur masyarakatnya. Namun pengertian dari E-Gvernment ini disebuah negara tidak liput dari kondisi internalnya baik secara makro maupun secara mikro bagi negara yang bersangkutan, sehingga dalam pemahamannya berbeda-beda.

Menurut hasil kajian dan riset Hardvard JFK School of Government dalam Indrajit (2006: 15-18) dalam penerapan konsep digitalis pada sektor publik, terdapat tiga elemen yang berhasil dan harus dimiliki secara sungguh-sungguh yaitu:

\section{1) Support}

Pada elemen pertama ini yang dikenal kursial oleh pemerintah yaitu keinginan (intent) dari beberapa kalangan pejabat publik dan politik yang benar-benar melakukan penerapan konsep egovernment, tidak hanya sekedar mengikuti zaman, namun juga menentang inisiatif yang bersangkutan dengan prinsip egovernment. Tanpa adanya unsur-unsur politik namun mustahil bagi inisiatif pembangunan dalam pengembangan egovernment ini berjalan dengan lancar karena disebabkan dalam birokrasi ini berkemungkinan bekerja secara model manajemen "top down" jelas saja kalangan dalam implementasi program e-government secara efektif dilakukan oleh pemerintah pada level tertinggi. Yang dikatakan dengan dukungan bukan hanya omongan semata, tetapi lebih kepada dukungan yang diharapkan yang dapat dideskripsikan sebagai berikut:

a) Disepakatinya kerangka $E$ Government terhadap salah satu kesuksesan negara dalam mendapatkan visi dan misi bangsa, yang kemudian harus diberikan prioritas seperti kunci kesuksesan lainnya.

b) Diterapkan sejumlah sumber daya (manusia, finansial, tenaga, waktu, informasi, dll). Disetiap tahapan pemerintah dalam membangun konsep ini dengan semangat lintas sektoral. 
c) Berdirinya beberapa infrastruktur dan juga superstruktur pendukung yang memungkinkan terciptanya lingkungan yang kondusif dalam pengembangan e-government (sepertinya adanya Undang-Undang dan juga Peraturan Pemerintah yang jelas). Diberikan penugasan kepada lembaga khusus, seperti kantor eenvoy sebagai penanggung jawab utama, kemudian diatur aturan main dalam bekerja sama dengan swasta.

d) Diterapkannya konsep-konsep egovernment secara keseluruhan, kontinu, konsisten, dan juga merata kepada semua kalangan birokrat secara khusus serta masyarakat secara umum dalam berbagai kampanye yang simpatik.

\section{2) Capacity}

Pada elemen kedua dapat diartikan sebagai suatu unsur kemampuan/ keberdayaan oleh pemerintah setempat dalam mewujudkan "impian" e-government yang berhubungan dengan kenyataan. Adanya tiga hal yang sekurangnya tidak perlu dimiliki oleh pemerintah yaitu sebagai berikut:

a) Tercukupinya sumber daya dalam melaksanakan beberapa inisiatif egovernment yang saling berhubungan dengan sumber daya finansial.

b) Tersedianya berbagai infrastruktur teknologi informasi yang cukup karena fasilitasnya mencapai $50 \%$ dari kunci keberhasilan dalam penerapan e-government.

c) Tersedianya sumber daya manusia yang dimiliki dalam menghadapi kompetensi serta keahlian yang diperlukan agar tercapai sesuai dengan asas manfaat yang diharapkan.

Perlu dengan memperhatikan ketiadaan satu atau lebih elemen prasyaratnya agar tidak terjadi alasan-alasan penundaan sebuah pemerintah tertentu dalam melaksanakan usahanya. Dalam penerapan e-government ini terdapat banyak fasilitas serta sumber daya yang beberapa berada diluar jangkauan pemerintah. Bahkan pemerintah mencari cara untuk dapat menghemat waktu dalam memenuhi persyaratan tersebut, contohnya usaha kerja dengan swasta, serta dengan pemerintah daerah atau negara yang merekrut SDM dalam sektor nonpublik.

\section{3) Value}

Pada elemen sebelumnya terdapat dua aspek yang dapat dilihat dari sisi pemerintah sebagai pemberi jasa. Beberapa inisiatif e-government tidak berguna apabila pihak tersebut merasa diuntungkan dengan adanya implementasi konsep ini serta dalam hal tersebut sangat menentukan manfaat yang didapat dalam penerapan egovernment. Namun dalam kalangan pemerintah sendiri, melainkan mereka yang berkepentingan tersebut. Oleh karena itu pemerintah dapat benar-benar memperhatikan dan juga memilih prioritas jenis apa saja aplikasi e-government yang seharusnya didahulukan dalam pembangunannya agar dapat memberikan manfaat yang signifikan didapatkan oleh masyarakat. Salah satu dalam mengartikan apa saja yang harus dipenuhi oleh masyarakat ini yang seharusnya akan mendatangkan bumerang oleh pemerintah yang kemudian akan lebih mempersulit dalam meneruskan usaha pengembangan konsep e-government ini.

\section{E-Government}

E-Government adalah suatu cara pemeritah agar dapat berkomunikasi dengan masyarakat dan juga dengan kalangan lainnya. Disertai dengan menggunakan teknologi informasi (terutama internet) yang bertujun agar dapat mengubah mutu (kualitas) pelayanan". (Indrajit, 2006) Dengan adanya teknologi informasi mengandung adanya sistem informasi, sistem informasi yang diartikan dalam suatu sistem terhadap suatu organisasi yang dapat mempertemukan kebutuhan pengolahan transaksi harian, 
mendukung operasi, dan menyediakan laporan-laporan tertentu untuk pihak luar (Aldri Firnaldi, 2014).

Pendapat lain mengenai e-government adalah suatu tolak ukur oleh pemerintah yang mengadopsi teknologi berbasisi internet yang bertujuan agar terpenuhinya kelengkapan dan peningkatan program dalam pelayanannya. Yang berniat agar dapat memberikan sesuatu yang lebih baik terhadap seseorang yang menggunakan jasa agar mendapat kepuasan secara maksimal (Conrad dalam Susanti, 2006).

\section{Manajemen Pengaduan}

Manajemen Pengaduan adalah adanya bidang administrasi publik yang memliki perbedaan namun agar dapat membedakannya bisa dilihat jelas dari kebijakan publiknya yang merefleksikan sistem otak dan syaraf, serta terhadap manajemen publik ini dapat dipersentasikan dalam sistem jantung dan juga sirkulasi dalam tubuh manusia tersebut. Kemudian dalam manajemen publik ini dapat ditarik kesimpulan bahwa dari keseluruhan kegiatan pengelolaan pelayanan publik yang telah dilakukan secara operasional oleh instansi pemerintah atau badan hukum lainnya yang diberikan kepada masyarakat berdasarkan kebijakan-kebijakan tertentu (OTT, Hyde dan Shafritz dalam Pasolong, 2007).

Manajemen Pengaduan (keluhan) bermula dengan adanya permasalahan yang ada dapat dilihat dari pelayanan publik, permasalahan tersebut timbul karena pemerintah maupun swasta. Dalam sistem informasi pengelolaan pengaduan saat ini tidak lagi muncul hanya dalam bidang usaha saja, bahkan ada juga terdapat dalam bidang pendidikan, pelayanan, industri, dan lainnya. Sistem diartikan sebagai suatu kesatuan komponen yang juga melekat dengan batasan pekerja yang dilakukan bersama untuk dapat mencapai suatu tujuan.

Maka hal tersebut dapat disimpulkan bahwa manajemen pengaduan itu jika adanya keluhan tersebut yag masuk maka dapat diartikan sebagai suatu bentuk hal penting yang dapat meningkatkan suatu pelayanan bagi masyarakat yang menggunakan layanan publik serta dukungannya terhadap pengguna pelayanan publik (pemerintah) tersebut.

\section{Layanan Aspirasi dan Pengaduan Online Rakyat (LAPOR)}

Layanan Aspirasi dan Pengaduan Online Rakyat (LAPOR) adalah suatu kanal pelayanan yang berbasis intenet berfungsi untuk mengelola semua penyampaian aspirasi dan layanan pengaduan bagi masyarakat sehingga media aplikasi ini memudahkan masyarakat dalam berinteraksi dengan pemerintah dalam hal pelayanan publik (Kominfo, 2020).

LAPOR di bangun untuk menerima pengaduan yang efektif oleh masyarakat agar permasalahan dari masyarakat terhadap layanan publik bisa diselesaikan secara cepat dan tuntas, dan juga masyarakat bisa berinteraksi secara langsung pemerintah tersebut sehingga tata kelola pemerintahan secara baik yang dapat memperkuat fungsi dalam pelayanan publik ini. Dalam pengawasan pelayanan publik yang dilakukan melalui pengaduan masyarakat ini dapat mencegah timbulnya potensi konflik dan juga memantu terciptanya rasa aman bagi masyarakat dan juga pelayanan publik dapat berfungsi secara maksimal.

Sebelum adanya Program LAPOR! di kota solok, pengelolaan pengaduan di lingkungan pemerintah kota solok hanya dilakukan secara konvensional. Yaitu melalui kotak saran, melalui surat, maupun dengan pengaduan langsung ke instansi penyelenggara layanan publik di Pemerintah Kota Solok. Namun hal tersebut tidak membuat perubahan dan masyarakat terkadang malas untuk melakukan dengan cara konvensional. Sehingga mengakibatkan laporan yang diberikan masyarakat tidak terkoordinasi dengan baik, tidak direspon dan terkadang diabaikan, tidak tuntas karena tidak ada kontrol kebijakannya. Hal inilah membuat 
masyarakat merasa enggan untuk memberikan aduan/ laporannya.

Dalam upaya memberikan sosialiasi kepada masyarakat, salah satu caranya ialah melalui penyebaran Benner kepada instansi pemerintahan di lingkungan Kota Solok. Tim pengelola LAPOR PEMKO SOLOK memberikan salah satu bentuk sosialisasi melalui penyebaran Benner. Seperti yang disampaikan sebelumnya, sosialisasi yang dilakukan oleh pengelola Program LAPOR PEMKO SOLOK tidak hanya melalui penyebaran Benner, namun juga malalui penyebaran stiker, spanduk, dan baliho. Juga melalui videotron yang ada dilingkungan Pemerintah Kota Solok, serta juga dilakukannya sosialisasi langsung kepada tokoh masyarakat sampai kepada tingkat RT dan RW se- Kota Solok. SP4N dalam (Kominfo, 2020) bertujuan agar:

1. Pengelolaan pengaduan dari masyarakat tersebut dilakukan dapat digunakan dengan cara mudah/sederhana agar dapat cepat terkoordinasi dengan sebaiknya.

2. Partisipasi oleh masyarakat dalam penyelenggaraan tersebut dapat dilakukan melalui penyampaian pengaduan.

3. Agar dapat meningkatkan kualitas dalam pelayanan publik.

\section{METODE PENELITIAN}

Penelitian ini merupakan penelitian pendekatan deskriptif menggunakan metode kualitatif. Penelitian kualitatif merupakan sesuatu yang memiliki tujuan dalam memahami fenomena yang terjadi atau yang dialami bagi subyek penelitian baik secara holistik dalam menggunakan pendeskripsian ini maupun dengan unsur kata-kata yang disusun dalam berbagai metode alamiah (Moleong, 2012). Populasi dari penelitian ini adalah seluruh OPD terkait dan pegawai Kominfo serta Pelapor. Teknik dalam mengumpulkan yang dilaksanakan oleh suatu unsur-unsur penelitian menggunakan wawancara, observasi dan juga analisis dokumen.
Tipe didalam penelitian kualitatif ini menggunakan pendekatan deskriptif, supaya dapat dilakukan dalam hal mendapatkan dan juga mengumpulkan data langsung dari lokasi penelitian tersebut mengenai penggunaan aplikasi LAPOR. informan dalam penelitian ini adalah Pegawai Kominfo dan juga masyarakat (Pelapor) Kota Solok. Teknik dalam pemilihan informan menggunakan pendekatan Purposive Sampling dimana informan dianggap sebagai yang paling mengetahui dan mampu memberikan informasi yang akurat terkait penerapan SP4N-LAPOR.

\section{HASIL DAN PEMBAHASAN}

\section{Penerapan Aplikasi SP4N-LAPOR dalam Manajemen Pengaduan Masyarakat di Kota Solok.}

Aspek-aspek penerapan E-Government yang dikemukakan oleh Budi Rianto dan Tri Lestari (dalam Nurul Wahida 2016: 3640) Ada beberapa kategori yaitu: Hadware dan Software, Data, Komunikasi dan Struktur Organisasi, Informasi, Human Resource (SDM), Sikap Pelaksana. Adapun aspek-aspek tersebut dapat diidentifikasi sebagai berikut:

\section{a) Hardware dan Software}

Dalam penerapan teknologi dan komunikasi harus terdapat kebutuhan sumber daya perangkat keras seperti komputer (hardware) atau bahkan jaringan global (internet). Dalam peningkatan sumber daya E-Government yang harus diperhatikan seperti penting adanya perangkat lunak yang terdapat didalam komputer (Software). Dimana software ini terbagi atas dua macam, seperti software operasi dan juga software aplikasi.

\section{b) Human Resource (SDM)}

Dalam SDM juga terdapat kedalam suatu organisasi, dimana didalamnya ada beberapa orang yang akan mengerjakan suatu aktivitas. Dalam SDM ini diperlukan orang yang mengerti terhadap teknologi informasi dan juga komunikasi. Yang memperdulikan perubahan atas SDM ini 
yaitu orang yang mempunyai tanggung jawab besar atas pekerjaan tersebut.

\section{c) Data dan Informasi}

Data dan juga informasi ini seringkali menjadi sumber data yang kurang mendapat perhatian didalam E-Government. Karena meski adanya kesediaan terhadap masukan untuk mendapatkan data dan informasi namun seringkali terjadi penyebarluasan informasi yang dapat melakukan perubahan atas tujuan dari E-Government meskipun sudah dalam bentuk lembaran kertas dan juga digital yang menjadi bahan utamanya.

\section{d) Struktur Organisasi}

Dalam suatu kebijakan yang ada didalam organisasi harus juga diterapkan peraturan untuk dapat dilaksanakan guna dalam menyelesaikan masalah atau bahkan mencapai tujuan tersebut. Setelah itu, barulah siapa dan juga bagaimana dalam pelaksanaan kebijakan E-Government tersebut. Sangat besar kemungkinan dalam melakukan penerapan kebijakan $E$ Government yang dapat dilaksanakan kepada lembaga struktur yang kemudian terdapat adanya dua maupun tiga tingkat di bawah top leader tersebut. Setelah itu harus adanya kesesuaian dalam melakukan kegiatan E-Government seperti melakukan tugas pokok kemudian fungsi dalam unit pelaksanaannya.

\section{e) Komunikasi}

Suatu kebijakan didalam E-Government terdapat suatu kewenangan dalam pemerintah pusat. Namun terhadap penerapannya sudah diketahui oleh lembaga pemerintah termasuk juga instansi yang ada didaerah. Yang mengetahuinya pemerintah pusat dan juga birokrasi yang berada dibeberapa daerah yang telah melakukan pelaksanaan tersebut juga sama halnya dengan persepsinya. Pemerintah pusat dan juga lembaga utama didaerah juga sudah mempunyai kewajiban atas penyebarluasan informasi mengenai $E$ Government. Proses dalam komunikasi tersebut dilakukan dengan arahan dan penjelasan agar forum rapat dapat memahaminya.

f) Sikap Pelaksana

Dalam sikap pelaksana ini dalam hal kebijakannya para pelaksana merespon baik hal tersebut. Respon pelaksana tersebut bersifat subjektif, dan mempunyai motivasi bahkan adanya niat dari pelaksananya. Namun adanya bentuk respon yang bersikap proaktif dan ada yang bersifat resistensi. Bahkan ada juga respon pelaksana yang terlihat dari bagaimana aktivitasnya. Namun jika pelaksana melakukan penerapan dalam kebijakan $E$ Government harus bersikap konsisten maka respon yang didapat akan menjadi positif.

\section{Kendala yang dihadapi dalam bentuk Penerapan Aplikasi SP4N-LAPOR dalam Manajemen Pengaduan Masyarakat di Kota Solok \\ a) Hardware dan Software}

Kendala yang pertama yaitu ketersediaan jaringan internet yang terkadang kurang mendukung dalam proses penindak lanjuti laporan pengaduan. Yang berdampak buruk karena mengakibatkan proses penyelesaian laporan yang dilakukan Dinas Komunikasi dan Informatika Kota Solok menjadi terhambat sementara waktu.

b) Data dan Informasi

Kendala selanjutnya yaitu masih kurangnya keengganan dari masyarakat untuk melakukan pengaduan ke dalam Aplikasi LAPOR! ini yang sebenarnya sangat membantu pemerintah dalam melakukan perbaikan atas pelayanan yang akan dilakukan. Yang dampaknya buruk karena hal ini juga akan mempengaruhi kurangnya tindak perbaikan pelayanan publik yang akan dilakukan oleh pemerintah tersebut.

c) Komunikasi

Pola komunikasi yang dilakukan berupa sosialisasi mengenai tata cara penggunaan dan pentingnya melakukan pengaduan terkait permasalahan pelayana publik yang akan membantu pemerintah dalam 
memperbaikinya. Namun bahkan berdampak buruk yang disebabkan oleh masih ada masyarakat yang tidak mengetahui adanya aplikasi LAPOR! Ini. Selain itu kendala dalam sosialisasi ini dikarenakan terbatasnya anggaran yang tersedia.

\section{Upaya yang dilakukan dalam bentuk Penerapan Aplikasi SP4N-LAPOR dalam Manajemen Pengaduan Masyarakat di Kota Solok}

Pihak kominfo berupaya untuk mengatasinya dengan melakukan pengusulan penambahan anggaran pada rancangan anggaran tahun berikutnya untuk sosialisasi dan pra sarana seperti komputer sehingga memadai dalam pengaplikasiannya. Hal ini dilakukan agar dapat semakin menyebarluaskan informasi tentang adanya keberadaan LAPOR!. sehingga diharapkan pengaduang oleh masyarakat akan semakin meningkat dan dapat berdampak baik dalam menangani pengaduan.

\section{PENUTUP}

Penerapan Aplikasi SP4N-LAPOR Dalam Manajemen Pengaduan Masyarakat di Kota Solok belum berjalan sebagaimana semestinya masih terdapatnya kekurangan yang berdampak buruk kemudian yang menjadi faktor pendukumg penerapan Aplikasi (LAPOR!) adalah aspek Hardware dan Software (tersedianya perangkat yang dibutuhkan untuk menjalankan LAPOR!), Human Resource atau SDM (adanya sumber daya manusia yang ahli dibidangnya), Data dan Informasi (tersedianya data dan informasi yang dibutuhkan), Struktur Organisasi (adanya kesesuaian kegiatan LAPOR! dengan tugas pokok dan fungsi unit pelaksana), serta Sikap Pelaksana (ditanggapi dengan baik dari Pelapor). Serta kendala yang dilihat dari permasalahan yang masih dihadapi yang berdampak buruk dari beberapa segi hardware dan software masih adanya kendala yaitu jaringan internet yang terkadang tidak berfungsi pada saat dibutuhkan. Dari segi data dan informasi masih kurangnya niat masyarakat dalam melakukan pegaduan ke dalam Aplikasi LAPOR. Dari segi komunikasi masih adanya pelapor yang masih belum mengetahui tentang Aplikasi LAPOR. Dari segi sikap pelaksana walaupun tanggapan pelapor sangat baik akan tetapi niat untuk melakukan pengaduan masih saja kurang. Upaya yang dilakukan dengan mengusulkan kenaikan anggaran untuk LAPOR agar sosialisasi dapat lebih ditingkatkan lagi dan pra sarana seperti komputer dan laptop bisa tercukupi dengan baik sehingga dapat berdampak baik dalam penerapan pengaduan.

\section{DAFTAR KEPUSTAKAAN}

Peraturan Presiden Nomor 76 Tahun 2013 Tentang Pengelolaan Pengaduan Pelayanan Publik.

Peraturan Presiden Nomor 3 Tahun 2003 Tentang Kebijakan dan Strategi Nasional Pengembangan EGovernment.

Peraturan Menteri Pemberdayaan Aparatur Negara dan Reformasi Birokrasi Nomor 24 Tahun 2014 tentang Pedoman Penyelenggaraan Pengelolaan Pengaduan Pelayanan Publik Secara Nasional.

Moeheriono. 2012. Pengukuran Kinerja Berbasis Kompetensi. Jakarta: Penerbit Raja Grafindo Persada.

Indrajit, Richardus Eko.(2006) Electronic Government: Strategi Pembangunan dan Pengembangan System Pelayanan Public Berbasis Teknologi Digital. Yogyakarta: Penerbit Andi.

Moleong, Lexy J. 2012. Metedologi Penelitian Kualitatif. Bandung: PT.Remaja Rosdakarya Bandung.

Pasolong, Harbani. 2007. Teori Administrasi Publik. Bandung : Alfabeta. 